on sticks to light the way. Rival companies raced to a fire, and it was a sporting event which of them should be first there. Many incentives were offered to the companies, who sometimes did what they could to slow up their rivals. Cast iron plates were fixed to houses insured by those insurance companies paying bounties to fire-fighters who saved insured property. The fire-fighters were in great demand for parades and political rallies, and no celebration was complete without them. Next came the days of steam fire-engines pulled by horses, and then the motor fire-engine.

\section{The Blue Water of Crater Lake}

Is the Cascade Mountains, Oregon, is the remarkable Crater Lake. It is about six miles long by four miles wide and lies within a volcanic crater the cliffs of which are 500-2,000 ft. high. Its depth in places is nearly $2,000 \mathrm{ft}$. It has no visible outlet, yet its water is fresh and is said never to freeze, although the surface is about $6,000 \mathrm{ft}$. above sea-level. It was discovered by white men in 1853, and was called the Deep Blue Lake. Seen from the rim of the crater, the water shades from turquoise blue along the shallow borders to darkest prussian blue in the deeper parts. From a boat, the colour deepens to dark indigo. Cloud shadows and wind flurries produce great variety in the appearance of the surface, but the main sensation produced in the eye of the observer is one of "unbelievable blueness". Dr. Edison Pettit, working on behalf of the National Academy of Sciences and the National Park Services, has recently completed a study of the reason for this extraordinary depth of blue (News Service Bulletin (School Edition); Carnegie Institution of Washington, 4, No. 4). He finds that the water has no special colour of its own, but that it is exception. ally free from suspended matter; such scattering of light as occurs in its depths is mainly from the water molecules, and is therefore deep blue. The degree of clarity is almost that of specially prepared dust-free water. The scattered light from dust-free water is blue at all angles; that from Crater Lake water is white only for a comparatively narrow forward angle, and at all other angles is blue.

\section{Wooden Pipe Lines}

THE use of wooden pipes as a means of conveying water dates back almost to prehistoric times. They were much used in the Middle Ages. During recent years, traces of the water supply system of London (c. 1600) by means of hollow trunks of trees have often been found during excavations. In World Power of May, there is a paper by T. Pausert, telling how wooden pipes made of staves and bound with hoops are coming into modern practice all over the world. Generally, the staves are made of pine or larch wood, and are planed off to give a smooth finish after assembly. The contact surfaces are dove-tailed. When the pipe is filled with water, the wood swells and becomes water-tight. These wooden pipes are either placed on the ground or laid in the open on supports. Their diameters vary from $5 \mathrm{~cm}$. to 6 metres. A great advantage is the immunity of the wood from the effects of water whether it is pure, acid, alkaline, saline or contains selinite. For this reason, wooden pipes are much used in the chemical industry. An important point is that salts are not deposited on the walls of the pipes, so that the latter do not become choked and their rate of flow affected. There is no risk of electrolysis from stray electric currents. If an increased pressure becomes necessary, it is easy to reinforce them by the addition of new steel hoops. If a sudden hydraulic surge occurs, the inherent elasticity acts as a safety valve; the staves being bound by hoops enable the longitudinal joints to let water escape in small jets. When the pressure comes back to normal, the staves resume their original position, and become water-tight again. Their cheapness, durability and the ease with which they can be transported in mountainous regions enable the power engineer to arrive at solutions to many of his problems by their use.

\section{Safety on the Roads}

The National Safety Congress was held in London on May 20-22. An account of the congress is given in Roads and Road Construction of June 1. At the Congress dinner, Sir Herbert Blain pointed out how much the British have learnt from the Americans in connexion with improving our roads and making them safer. In particular, he mentioned the practice of coloured traffic lights and of one-way streets. Although there is a magnificent system of roadways in Great Britain, there are no roads that can compare with some of the roads now being laid in America. These national highways are very wide and have a beautiful surface, good elevation and proper lighting. The curves are properly rounded, and there is no ribbon development. Mr. A. Matheson, the assistant secretary to the Minister of Transport, read a paper on "Danger Spots". Experiments have been carried out in London, where certain roads with black records have been selected. A study of these records showed that a large fraction of the accidents occurred to pedal cyclists and pedestrians. These roads were then inspected and improvements suggested which it is hoped will diminish the number of accidents. In two of the roads where the work recommended has been completed, a record was kept for six monthe.

In the Chiswick High Road, the number of accidents as compared with the corresponding six months of the preceding year was reduced by 37 per cent, and in the Fulham Palace Road to Putney Bridge the reduction has been from 88 to 48 , or nearly 45 per cent. The Oxford County Council, becoming alarmed at the large number of accidents on its roads, made a detailed investigation of them over two years ending July 1934. The investigation showed that nearly one half of the fatal accidents occurred on certain main roads constituting less than six per cent of the total mileage of the county. During the first seventeen weeks after making certain improvements, it was found that, compared with 
the corresponding seventeen weeks of the preceding year, the fatalities were reduced 52 per cent and the number of injured $11 \cdot 6$ per cent. In Glasgow it was found that the installation of light signals at certain junctions reduced the number of accidents by about 75 per cent.

\section{Farmer's Guide to Agricultural Research}

For the past ten years, the Royal Agricultural Society of England has issued annual summaries of research work carried out in the leading branches in agriculture. The publication, known as the "Farmer's Guide to Agricultural Research", is now issued as a section of the Society's Journal, so that it may be automatically in the hands of all members. A fow copies are published separately for private circulation, and a limited number of copies of previous issues (1925-33) are still available. The Society has now published its Journal for 1935 (vol. 96). The various sections of the Farmer's Guide are similar to those of the previous year, as are also the authors responsible for them. The remainder of the Journal consists of a number of special articles of outstanding interest, reports of the research work carried out under the ægis of the Society, together with a number of official reports. The volume may be obtained from the headquarters of the Society, 16 Bedford Square, London, W.C.1 (price 15s.).

\section{"Index Generalis"}

THE editor of the "Index Generalis", the 1936 issue of which was noticed in NATURE of July 18 (p. 100), asks us to state that new items for inclusion in this reference work are welcomed. They should be in the form in which they are to appear in print, and should be sent to Prof. R. de Montessus de Ballore, directeur de l'Index Generalis, Sorbonne, Paris $V^{e}$. No charge is made for insertions, and there is no obligation to purchase the volume. The only stipulations are that the information should be up to date and that it be revised annually on the request of the editor.

\section{Announcements}

Mr. R. Coppock, general secretary of the National Federation of Building Trades Operatives, $\mathrm{Mr}$. Richard K. Law, M.P., and Prof. B. A. McSwiney have been appointed members of the Industrial Health Research Board of the Medical Research Council.

Prof. A. Matae, professor of botany in the University of Lille, has been elected Correspondant of the Section of Botany of the Paris Academy of Sciences, in succession to the late Prof. H. Jumelle, professor of botany in the University of Marseilles.

The Trustees of the Busk studentship in aeronautics, founded in memory of Edward Teshmaker Busk, who lost his life in 1914 while flying an experimental aeroplane, have awarded the studentship for the year 1936-7 to Mr. J. W. E. Clarke, Glasgow.
Prof. Paut Uhumnuuth, director of the Institute of Hygiene at Freiburg i.B., has been nominated a foreign member of the Royal Academy of Sciences of Stockholm in recognition of his outstanding contributions to hygiene and bacteriology.

THE twenty-eighth annual Autumn Meeting of the Institute of Metals will be held in Paris on September 14-18. The fifteenth Autumn Lecture will be delivered. in the Grande Salle, Maison de la Chimie on September 14, at 8 p.m., by Prof. P. A. J. Chevenard, who will speak on "The Scientific Organization of Factories". Further information can be obtained from the Secretary, Institute of Metals, 36 Victoria Street, London, S.W.1.

A provisionax programme has been issued of a General Discussion of the Faraday Society to be held in the Chemistry Theatre, University of Edinburgh, on September 24-26 on "Structure and Molecular Forces in (a) Pure Liquids and (b) Solutions". The scope of the meeting does not extend to kinetics, which will form the subject of a forthcoming meeting, or to subjects which have been dealt with at recent meetings, such as dipole moments and the theory of strong electrolytes. A general introduction is promised by Prof. J. Kendall. The introductory paper in Section A (Pure Liquids) will be by Prof. F. London (Oxford), and that in Section B (Solutions) by Prof. J. H. Hildebrand (Berkeley, California). As is usual in these discussions, a number of foreign guests have been invited to take part. Particulars of the meeting can be obtained from the Secretary, Faraday Society, 13 South Square, Gray's Inn, London, W.C.1.

Applicatrons are invited for the following appoint. ments, on or before the dates mentioned :

An assistant for abstracting, indexing and proofreading in the Imperial Bureau of Animal Nutrition, Rowett Research Institute, Aberdeen-The Deputy Director (August 3).

An assistant lecturer and demonstrator in physics in the University of Leeds-The Registrar (August 10).

A lecturer in physiology (Grade II) in the Uni. versity of Bristol-The Registrar (August 12).

A general inspector of education and research, agricultural and horticultural division of the Ministry of Agriculture and Fisheries-The Secretary, Minister of Agriculture and Fisheries, 10 Whitehall Place, S.W.1 (August 12).

A professor of physics (August 31) and an assistant in bacteriology (August 20) in the University of Cape Town-The Secretary, Office of the High Commis. sioner for the Union of South Africa, Trafalgar Square, London, W.C.2.

Structural engineering assistants for the Designs Branch of the Directorate of Fortifications and Works-The Under-Secretary of State (C. 5), The War Office, London, S.W.1.

A physicist or applied mathematician to the British Cotton Industry Research Association-The Director, Shirley Institute, Didsbury, Manchester. 